\title{
Feminist affect and children's embodied trauma
}

\section{Anna Hickey-Moody \\ RMIT University \\ Marissa Willcox \\ RMIT University \\ DOI: https://doi.org/10.1344/jnmr.v1i2.30911}

\section{Abstract}

Feminist new materialisms account for the agency of the body and the ways it is entangled with, in and through its environment. Similarly, affect scholars have put words to the bodily feelings and attunements that we can't describe. In this paper, we provide a brief survey of feminist thought that established the scholarly landscape and appetite for the turn to affect and offer this as a theoretical tool for thinking through the child body. Feminist affect is used here as a resource for understanding embodied change in children who are living with intergenerational trauma. Through analysing data from the Interfaith Childhoods project, we explore art as a way to affectively rework trauma in three case studies with refugee children from our Australian fieldwork sites. Our new materialist arts based approaches map embodied changes in children that speak to how bodies inherit and are affected by things that often can't be described. Specifically, in relation to their religious, cultural and refugee histories (Van der Kolk 2014, Menakem 2017), we offer the analysis in this paper as a route towards understanding children's bodily experience and expression, in ways that have been made possible by affective lines of inquiry pioneered by feminist scholarship.

\section{Keywords}

Affect; new materialism; body; trauma; epigenetics; childhood.

Affect is in rooms, in texts, in averted glances, in speeches, in dreams, in crying jags and in lecture notes, in philosophy and in poetry, in theories and in bodies. 
It has a deeply un-Cartesian lack of respect for or knowledge of the membrane of the skin, the boundary between the self and the world. (Kluchin, 2012, p.1)

\section{Introduction}

Affects are movements that can change people. Produced by assemblages connecting bodies, contexts and objects, affects are the result of more-than-human connections: art materials, times of making and collaborating, ways of presenting and being received. Affects are bigger than the people they change. Above, Abigail Kluchin explains affect as the intensity that no one body is able to own; the empirical and emotional mixture we don't have a feeling or proper noun to describe, the in-between zone of things that makes us question boundaries between knowledges, bodies, practices. Shifting shapes and locations, affect escapes language but can also be in language. As such, affect can be transgressive: leaking between bodies and ideas and showing up the edges of 'thought'. Embodied histories and knowledges live on for generations in affect, and as such, affect is also often the medium for maintaining or resolving generational trauma, memory and biography. Affect can reproduce and enforce existing hierarchies of power through looks of distaste, through suggestion, through praise, through a disapproving raised eyebrow. Its power is partly derived from the unacknowledged, often unconscious ways that affect works: it changes states of affairs and then minds follow.

Feminist theory has long been interested in the body as a site of transgression, attuned to a myriad of practices of epistemic and corporeal boundary crossing, creating ways of mapping the un-nameable. Such content includes unspoken but effective/affective power dynamics, the non-verbal exchange of information, and spatial and structural inequalities. What is now called 'affect theory' is concerned with discussing matters that had, until the late 90 s and early 2000s, been the preserve of feminist theory. Indeed the "turn to affect" (Clough \& Halley, 2007) or "affective turn" (Cvetkovich, 2012), as it has been characterized, has predominantly been concerned with building on the work of male theorists who advance arguments that have implicit, uncited relationships to feminist theory. While there have been efforts to produce feminist genealogies that recognize the often undercited and uncredited work of woman thinkers (see, for example, van der Tuin, 2009, 2016; Buhlmann et al., 2017), citational practices that acknowledge the feminist history of the subjects of affect 
studies have not been comprehensively taken up within the field. Redressing this issue, we use the idea of 'feminist affect' as a way of thinking through the child body to understand embodied changes that are prompted through art practice.

\section{Method and methodology}

As a methodology, thinking through feminist affect to read the child body requires acknowledging corporeal agency and the complex temporalities this brings with it. Children are born with the histories of their parents' and their forebears' imprinted in the matter of their bodies (Haines, 2019). Children's bodies speak for them, but also speak of their families' and their own inherited histories (Menakem, 2017). This approach is put into action through the Interfaith Childhoods research project methods, which work with art and embodied affect to understand children's expression of themselves, their identity, faith, community and belonging. Interfaith Childhoods works with schools, communities and religious organizations to collect and share stories of everyday life told by secular people and those of faith in Australia and the U.K.

This large empirical research project, which we discuss in greater detail later on, has a number of research participants who speak languages other than English, but the images they create communicate affectively, regardless of language. Through new materialist ethnographic work, we look for everyday stories and experiences of belonging that emerge through a collaborative art making process. These experiences are shared through images, words, memory, allegory and collaborative exchanges. Reading the child body, making together and observing bodily responses is a way of creating space to recognize subjugated, non-mainstream knowledges. Making art with culturally and linguistically diverse children and talking to their parents is an everyday, vernacular, decolonializing approach to a feminist affect. Our approach is concerned with the agency of experience, of places, matter and things.

Interfaith Childhoods has 13 fieldwork sites and over 500 participants. Through new materialist arts workshops with children aged 5-12, we explore how children and their parents feel they belong (or do not belong) to Australia or the UK, and to their religious, ethnic and cultural identities. Art making and focus group conversations with parents form a complex enmeshment of stories, symbols and styles of attachment emerge. This data needs to be read through bodily experiences of, migration, war, trauma, 
Othering, but also love, acceptance, intercultural/interfaith friendships, respect, family, food and more. We employ feminist affect to explore some of the children's embodied changes and behavioural traits which are often expressions of religious and cultural histories, generational trauma or refugee pasts.

Our method acknowledges the centrality and importance of vernacular culture, and responds to the agency of matter and political landscapes that shape global flows of faith and local communities. This methodology recognizes that meaning and communication are often non-verbal and are constituted in the vital present in ways that are shaped by complex political, social and cultural histories. The methods for collaborative art making which Anna Hickey-Moody developed, make space for a decentring of colonial histories and for non-verbal affective communication in research with children. These methods span across a range of media and employ an array of practices that offer different articulations of her theory that attachments and orientations are often experienced and performed unconsciously (2009, 2013, 2017, 2018).

\section{Affect, epigenetics and trauma}

Spinoza's concept of affect needs to be considered before Deleuze's (1988), as it is the source from which Deleuze derives his model. Spinoza (1677) maps the work of "affections" (which he calls affectiones): affections create modifications or qualities, and Spinoza says that the affects consist in "the affections of the body whereby the body's power of acting is increased or diminished ... together with the ideas of these affections" (1677, IIID3). Sad affects are those by which a body's capacity to act is diminished. As an example of this, Hickey-Moody has argued elsewhere $(2009,2019)$ that disability is too often read as a source of sad affect, as a means of reducing a body's capacity to act.

Spinoza asserts that the mind is constituted by its idea of the body; however, we become aware of the body through the ways it changes. So, affects, both active and passive, constitute the body-mind - but these affects are able to be modified in thought as reason and/or intuition. Passive affects reduce capacity to act, and active affects increase capacity to act. This definition of affect as a body-mind connection, linked to capacity, also shapes Deleuze's work on affect. For Deleuze (1990), an affect is an 
increase or a decrease in the capacity to act of a given assemblage (a body, object, or network)1. This method of thinking carries on in the work of many others (e.g. Massumi 1995) and can be characterized as a canon.

Other popular resources for working with the concept of affect include Silvan Tomkins, Eve Sedgwick, Moira Gatens, Marie Luise Angerer, Gregory Seigworth, Bernd Bosel, Patricia Clough, Brian Ott, Elspeth Probyn. Tomkins (1962, 1984, 1992) defines affect in a much more psychologically aligned (or human-centric) way than Spinoza or Deleuze. For Tomkins, affect is also the innate, biological response to the increasing, or decreasing, of neural firing. This can be read as a biological and anthropomorphized way of saying that affect is an increase or decrease in capacity to act. Awareness of an affect is a feeling, and a feeling in combination with a memory of prior similar feelings, is an emotion. Out of awareness, we develop 'rules' that we use to achieve more positive and less negative affect. Tomkins calls these "scripts". The pattern of scripts that a person uses to modulate affect constitutes their personality. Epigenetics (Youdell 2016) and trauma studies (Van Der Kolk, 2014; Menaken, 2017; Herman 1992; Miller et al., 2020) show us that people's 'scripts' are often inherited and then activated and rewritten in different ways. Van Der Kolk (2014) explains:

Recent research has swept away the simple idea that "having" a particular gene produces a particular result. It turns out that many genes work together to influence a single outcome. Even more importantly, genes are not fixed; life events can trigger biochemical messages that turn them on or off .... While life events can change the behaviour of the gene, they do not alter its fundamental structure. Methylation patterns ... can be passed on to offspring-a phenomenon known as epigenetics. Once again, the body keeps the score, at the deepest levels of the organism. (p. 175)

\footnotetext{
1 The more recent two philosophers in this trajectory of affect are Henri Bergson and Brian Massumi. They again develop related or derivative concepts of affect. Matter and Memory (Bergson 1988) is a key text in which Bergson links cognition and affect. He defines affect as "that part or aspect of the inside of our bodies which mix with the image of external bodies" (1988, p. 60). This 'part or aspect' is necessarily produced by perception and "there is no perception without affection" (1988, p. 60). Again, we see a link between the 'outside' and 'inside' of a person: affect is a process of mediation, and a process of change. Massumi (1995) derives his idea of affect from the theorists cited above. He draws on Spinoza, Bergson, Deleuze, and Guattari to develop relationships between intensities that escape coding as being singularly psychological, or singularly emotional, and he writes about such intensities as affects. For Massumi, affect is "the edge of virtual, where it leaks into the actual, that counts ... It is beyond infrastructural. It is transversal" $(1995$, p. 105, 107). Affect activates materiality through embodying new connections and machining the possibilities that come with these enmeshments. Bringing the actual into the virtual is affect's utility.
} 
An openness to working with a biosocial reading of the body that takes the physiological aspects of affective processes seriously informs our method and approach to 'feminist affect'. Youdell explores how epigenetics, sociology, pedagogy, and molecular biology might come together to enable biosocial orientation in education. Epigentics, the study of gene expression, looks at "the plasticity of the brain's epigenetic responses to environment and experience" (Youdell, 2016, p. 57). Youdell points to studies that look at biochemical changes in the brain in relation to changing environments, affects, and situational knowledges, in order to theorize how children learn, the relationships between the child, body, memory and community. Pointing to the molecular ways humans are changed by what and whom they see, Youdell (2016) says:

when a child is not acting their place in the discourse of the good student, it might not be because they are recalcitrant, disordered or disruptive-it might be because their stress access or their social behaviour network is responding to the situation in a way that makes it difficult for them to be and do who and what the teacher wants. (p.58)

Youdell presents learning as a process between intra-acting elements of electrochemical activity, community, relationships. This is a perspective we also adopt through feminist affect. We consider the biosocial orientation of the childs' body in the classroom, through considering acting out, hiding, disengaging or disrupting. Extending Youdell and Van der Kolk's work, we offer art practice and feminist affect as resources for thinking through the childs' body to readdress or unpack trauma. Affect theory, epigenetics and trauma studies share a conviction that somatic and creative physical work can change inherited and embodied histories. They are complementary theoretical perspectives. We work with children of low socio-economic and linguistically diverse backgrounds to express themselves. When asked to draw about home, often angry scribbles or fallen buildings appear. Then speaking to the children's parents after our workshops, we are given even further opportunity to explore where their trauma of home may come from. For many children that create unusual works when drawing about home, their parents describe their experiences of displacement due to war or crisis. This response, like Miller and Shakespeare Finch's (2020) work speaks to how bodies hold onto things, how our genetic coding is not indeed fixed, and that through an ontological exploration of trauma, feminist affect is 
one of the most useful tools with which to think through the child body.

\section{Feminist affect}

Before the 'turn to affect' (Clough \& Halley, 2007), there was feminism, which created an appetite to think through the body (Gallop, 1990) and legitimized embodied knowledges. We offer a gallery-style tour through the work of some contemporary theorists of feminist affect in order to show that the scholarship on affect canvassed above has parallels with a feminist canon. Thinking with feminist affect, we have the opportunity to open up more pathways that acknowledge the body as a site of labour, embodied history and political action. Valerie Walkerdine was crucial in creating a scholarly climate that values embodied histories and knowledges, and this culture of thought is key to the uptake of affect theory. Here we look at Walkerdine's recent writing, but also consider her earlier research a significant precursor to contemporary work on affect, as Walkerdine developed spaces for exploring psycho-social transference now occupied by affect theory. Walkerdine's article (2016) "Affective history, working-class communities and self-determination" develops a useful concept of affective history, exploring "the common creation of everyday being-ness, producing ... meanings that may have existed and been passed down over hundreds of years" (p. 699). Her psychosocial history of class provides tools for understanding affective structures of feeling that extend beyond class strata, to include the intersectionality of race, gender, sex, place, and other significant factors. Walkerdine (2017) further develops her psychosocial affective history to think beyond class, into the ways it emerges through struggle, resilience and aspiration. She argues that: "the great class divide ... has to be understood in terms of the psychosocial affective history of its production" (2017, p. 6).2 This history of class production is foundational in considering the ways children are produced and read as classed, and their responses to this positionality. We draw on Walkerdine's thought below in considering the ways two refugee boys from a council estate acted out against the classed nature of their geographic position.

2 Walkerdine cites Deleuze, Guattari, Studdert, and Barad in developing this argument, while Bev Skeggs' work on class haunts the text. 
Lisa Blackman's (2015) "Affective politics, debility and hearing voices: towards a feminist politics of ordinary suffering" provides a significant resource for those thinking about how affect shapes our social worlds3. As an intervention within queer and feminist debates that have re-posed negative ways of being, Blackman (2015) suggests that feminist futures that are attentive to the relations between affect, feeling and politics will offer new strategies of survival in capitalist countries. Blackman's vision importantly de-medicalises feeling beyond an individual expression of psychopathology. We also argue for a feminist reading of affect theory that accounts for the dissociative bodily affects of adults and children, and draw on Blackman's work in order to think about the detached persona of a refugee mother who has survived the Bosnian war.

In "De-colonizing empathy: thinking affect transnationally", Carolyn Pedwell (2016) "examines empathy's dynamic relationships to transnational processes of location, translation, imagination and attunement" (p. 29). Pedwell argues we need to pay

attention to the ways in which feelings travel, and the political implications of such mobility needs to be combined with attention to the significance of contingent social and geo-political location and positionality. ... embodied location and geo-political context matter to the production of affect, to the particular ways in which empathy might work and gain significance. (2016, p. 46)

This attunement to the geopolitical politics of emotion is critical, especially as we are two white women working with children of colour from migrant and refugee backgrounds. We look to decentre colonial histories, knowledges and value systems, and also to develop an awareness of the global and racialized politics of emotion. The example of empathy that Pedwell mobilizes is useful, as empathetic engagement can be seen as a colonial trope applied to the black child. We try to create a middle ground which does not patronise refugee children by empathising with them, but also, arguably more unethical, does not urge towards simply observing or analysing their process. Reading and responding to their verbal and non-verbal communication, we are part of the assemblages through which they become.

3 Blackman cites Berlant, Ahmed, Cvetkovich, Puar, Walkerdine, Spinoza, and Deleuze 


\section{Affect as a feminist politic and pedagogy}

Hickey-Moody has written on affect as pedagogy (2013), advancing the argument that culture and art are pedagogical. She has theorized this process of how change occurs in the body through the idea of economies of affect (2009). The phrase "economies of affect" refers to the embodied changes created through affect, the relations that take place to facilitate these changes and the ensuing relationships they make possible: diffractions that run through bodies and cultures. This project began as a book in which she considers the original dance theatre work of performers with an intellectual disability as a way of understanding how they develop and present new public pedagogies of disability (Hickey-Moody, 2009). In building this argument, she draws in detail on the work of Spinoza, Deleuze, and Guattari, to craft a frame for reading bodies and aesthetics as pedagogical. She theorizes an 'open body' as the collective corporeal assemblage that communicates affectively. This thinking is continued in her book (Hickey-Moody, 2013), where she develops a theory of 'little publics': these are communities of young people who perform civic participation and develop identity politics through artworks that call their local public to attention. The concept of little publics is also useful for thinking through the work of young people broadcasting their identity online and understanding the affective economies of youth online communities. More recently (Hickey-Moody, 2019), she has examined affect as a means of understanding gendered performances and taken up Deleuze's work more broadly as a methodology for reading gender. We continue this line of inquiry, concerned with the ways material changes have social and political impacts in our analysis below.

Julia Coffey writes about 'body work' and the ways gender is ascribed, restructured and made through a Deleuzian analytic of 'becoming'. Coffey's (2013) article "Bodies, body work and gender: Exploring a Deleuzian approach" articulates how, through thinking with affect, "body work must be understood as embodied processes which move beyond binarized analyses of the body" (p.3). She argues that "body work practices can be more productively understood in this context: as processes (rather than a 'project') related to identity, and as a series of practices of negotiation among many that are meaningful to the ways bodies are lived" (p.7). Thinking within this frame, as bodies being events, Coffey contends that "the body is productive because 
it connects (Deleuze and Guattari, 1987); and a focus on these connections ... bridges the gap between gender as a concept and as an embodied experience" (p.7). Coffey's work not only thinks through the body, it thinks through the ways the body is made in an interactive becoming within feminist research. She calls for further inquiry into feminist lines of affective thought which account for body work and practice 4 . We align with Coffey's position that the body is productive in its connections and this approach is evident in our analysis of children's processes of making below.

A substantive contribution to thinking about affect as pedagogical has also been made by Alyssa Niccolini. Niccolini's (2016) piece "Terror(ism) in the classroom: censorship, affect and uncivil bodies" "examines an event in a US secondary classroom where a Muslim student was disciplined for reading lesbian erotica in class" (p. 893). In an inquiry similar to the reframing of dominant readings of religious culture undertaken by the Interfaith Childhoods project, Niccolini is interested in "post-9/11 practices of surveilling and managing Muslim bodies and ambivalent affects around Muslim women'” (2016, p. 894). Niccolini argues that a lesson can be learnt from practices of surveilling and managing Muslim women's bodies, stating: "Incivility and dissent ... are important affects to make space for in secondary schools, particularly for students of color" (2016, p. 893). We adopt this approach in our analysis below, which consists of the stories of three children, each of which begins by 'acting out', or to use Niccolini's words, by demonstrating "Incivility and dissent".

This brief 'gallery tour' of contemporary feminist affect theorists shows us the link between feminist scholarship and affect theory. We have footnoted the academic resources used in these chapters, when the affect scholarship recognizes a feminist canon. To demonstrate the utility of a feminist canon of affect studies then, we put forth three empirical case studies from the Interfaith Childhoods project. We use feminist affect here, in line with the above works, to understand our case studies through the lens of feminist affect and new materialism, which are united by shared beliefs in:

1) The body as a site of labour, racialized and classed place of political action.

2) Power and politics as mediated through materiality and action.

${ }_{4}$ Coffey cites through a more feminist cannon of affect than the rest, she cites Barad, Budgeon, Butler, Braidotti, Colebrook, Coleman, Deleuze, Gatens, Grosz, Hickey-Moody and Malins, 
3) Non-verbal communication as a significant method of expressing affect.

These three beliefs can be seen to unite feminist affect studies as a field. We now turn our focus to employing feminist affect to undertake analysis which thinks through the child's body, inherited trauma and their imaginary worlds.

\section{The child body}

Children and embodiment is to subject of much excellent new materialist work (Malone 2016; de Frietas and Sinclair, 2013). The racialized nature of children's bodies is a primary way they communicate, as Franklin-Phipps (2017, p.385) explains:

The shifting ways that Black girls bodies can affect and be affected in relation to entering an assemblage is becoming. Becoming amplifies, makes space for noticing, and emphasizes what a girl can do in a given assemblage; it is a recognition that affective power is fluid even as it is mediated and constituted by race and gender ... Becoming is not inherent in the girl, but a result of a variety of factors acting in concert to effect particular kinds of becomings for particular kinds of bodies. This way of thinking about girls is one of accounting for girls' agency without undermining or minimizing the structural forces that move and affect her.

As this quote makes plain, context matters. We need to think through how child's bodies express themselves, often unknowingly, in ways they can't often comprehend. How does a child of a refugee background express fears of homelessness or displacement in relation to their past trauma of fleeing war? Through black scribbles? Words often aren't enough. This is precisely why we have devoted this article to using feminist affect as a way of thinking through the child body. Brownlie et al. (2011) in their work on infant bodies, give us insight into how young bodies are often left out of sociological research. Because infant and child bodies are often theorized as 'unfinished', or as 'biobundles', regulated through state intervention, Brownlie et al. (2011) urge the reconsideration of infant bodies as 'social bundles' instead, which account for the many entanglements that make up the ways their bodies are affected by the social and cultural world. We go onto extend this argument through thinking with feminist affect, arguing that social bodies are not only raced, classed and gendered (Lugones, 2016) but carry stories that remain unknown to them. With three 
empirical case studies presented below, we offer routes to thinking through the child body that acknowledge both the agency and affectedness of living with intergenerational trauma and expressing this through art.

The ordinariness of rubble and fallen cities: Amira

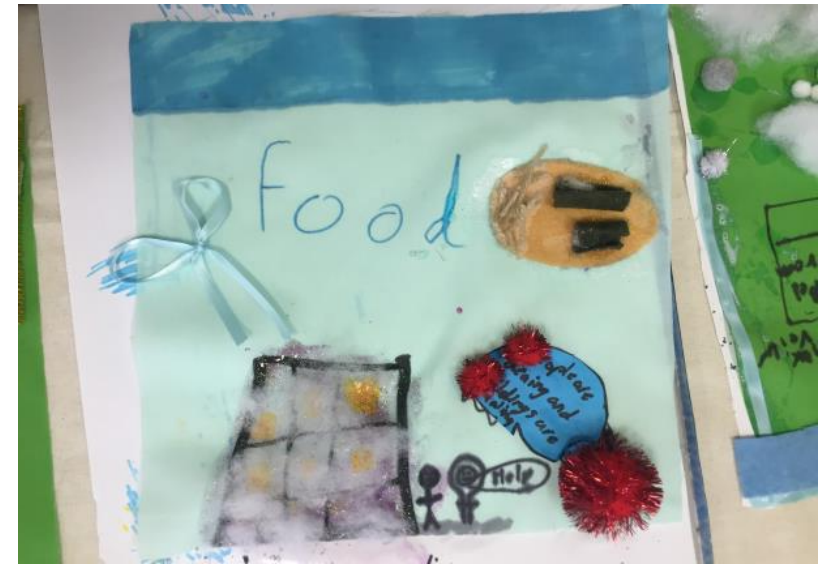

Amira's quilt square about home, "food and falling buildings" Canberra, 2019

This image shows a fabric square, made by an 8-year-old Muslim girl in Canberra Australia. At a religious school, we ran a series of children's arts workshops in 2018 and 2019 that explored feelings of community, identity and belonging and held focus group discussions with parents. This mixed media fabric collage was part of a belonging quilt we made where we asked the children to draw about 'what really matters' and what 'belonging feels like'. We later stitched together the patches of material to make one large quilt. Amira drew about food, friends and her home in Syria. As a refugee, when asked to draw about her home, or feelings about where she belonged, Amira drew buildings falling on people. In a nonchalant way, she asked us to google 'rubble' and 'fallen cities' to help her draw an image that represented her home. The talking bubble in blue says: "People are dying and buildings are falling". The image of the woman wearing a hijab yelling "Help!" is her grandmother. Amira told us her grandmother still lived in Syria, and when the war was over, she wanted to go back to see her grandma, but right now her Grandmother's house had no roof (because of air raids) and that it wasn't safe. Amira's acclimatization to urban destruction and the war that caused it was presented through an "everyday beingness ... that may have existed and been passed down" (Walkerdine, 2016, p. 699). Amira's tastes in fashion and textiles also echo the histories of Syria's rich and refined 
textile industry. While she was sullen, shy and withdrawn the first day, by the second day she trusted us more and became expressive, decorating everything with coloured glitter. Blackman (2015) refers to changes such as this as "affective capacity [which] is bodily capacity and draws attention to the liveliness and materiality of matter and to processes taken to exceed and de-stabilise the primacy of cognition and conscious attention in theories of power (such as interpellation)" (p.35). On the final day of workshops, when we were meant to leave the school, Amira hugged us and made all of the workshop facilitators handbags out of paper stuffed with notes and drawings. Amira wants to be a fashion designer when she grows up.

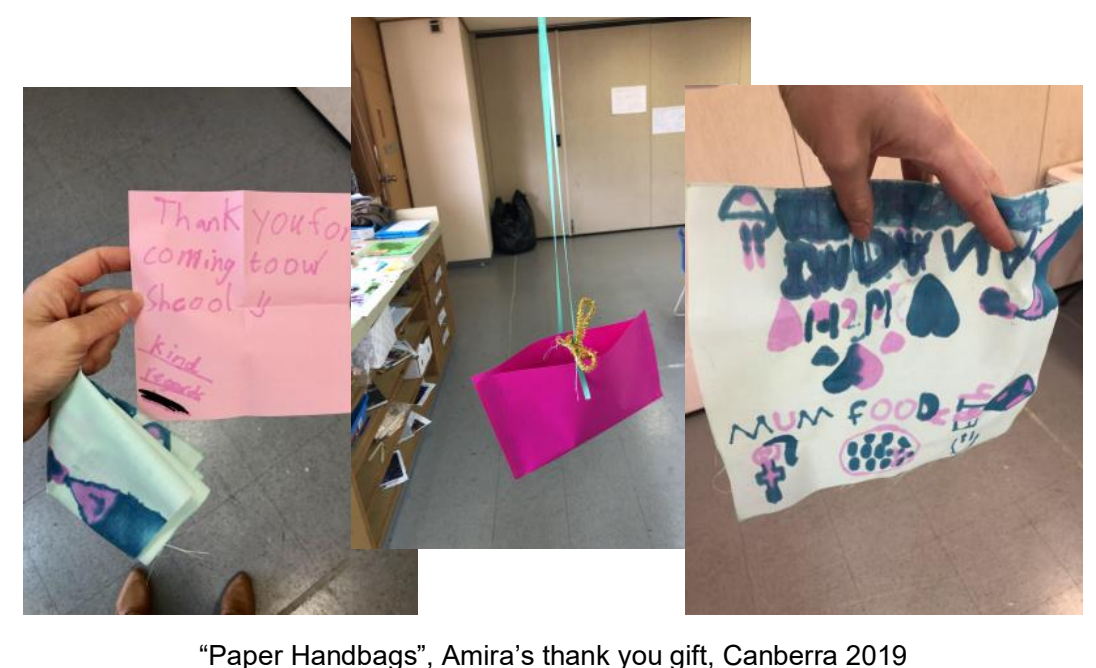

Working with feminist affect as a way of thinking through Amira's lived experience as a refugee, her connection to food, family, and the war back home, we see that art practice offers only an entry point to navigate her feelings around these issues, but a way to consider how lived experiences and bodily affects play out on the page. The act of drawing and making expresses and uncovers embodied traumas through material engagement (Kalmanowitz and Ho, 2016, 2017; Rowe et al. 2017; Ugurlu 2016). By the third day, when we moved onto new bodily capacities and exploring what 'community' looked like, Amira's drawings became more about clothes and food and friendship, they strayed away from the images of burnt cities. Our intention is not to provide art 'therapy', yet we could not help but notice that the making can serve as a therapeutic route towards dealing with the often unarticulated issues of intergenerational trauma, displacement and belonging among children. Through their assessment of art therapy interventions with refugee children, Ugurlu et al. (2016) 
point out that, "sometimes it could be difficult for a child to talk about traumatic experiences" and they "observed that children did not know and could not express their feelings. However, through art therapy, they began to learn their feelings and gained insight into their problems...They learned how to relieve negative emotions" (p.98). For Amira, talking about home and belonging in an unthreatening way, with a practical focus, brought out images of war-torn cities, but also of food, fashion and family. Drawings of the place where Amira was from as opposed to where she was going served as a road map for us to understand bodily affects, through both their limited capacities and their possibilities.

\section{Zoltar and the impermanence of fortune}

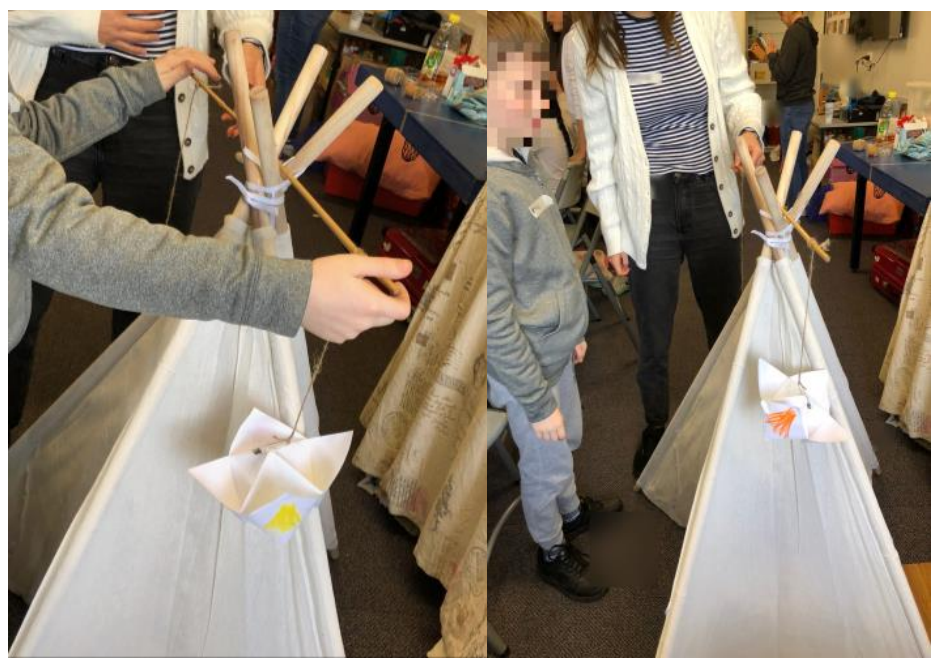

Zoltar's fortune teller, "Finding refuge in the future", East Melbourne, 2019

Zoltar the Great is a pseudonym for a catchier magician's name that one of the participants from East Melbourne made up when he reinvented himself as a 'magical' fortune teller. This moment of reinvention was critical, as it was the point at which the boy moved from being completely disengaged to being an active participant in the workshop. Having the power to tell fortunes, and perhaps the associated idea that he can make his own fortune, transformed the way that Zoltar felt about himself. Coffey's (2013) writing on feminist affect through body work shows us how a body's "becoming happens in the event, or process, of connections... Body work practices can be more productively understood in this context: as processes (rather than a 'project') related 
to identity, and as a series of practices of negotiation among many that are meaningful to the ways bodies are lived" (2013, p.7). For Coffey, bodies are the things that are lived, as opposed to the things that do the living. Zoltar's family immigrated to Australia from Bosnia before he was born, and the experience of war has clearly impacted significantly on all his family members. Memories and lived experiences have been passed down either biologically, socially or pedagogically through a process of events, which make up the ways his body is lived. An example of this is when Zoltar drew his home in one of our animation workshops as a thick black scribble that eventually covered the entire screen of the iPad.

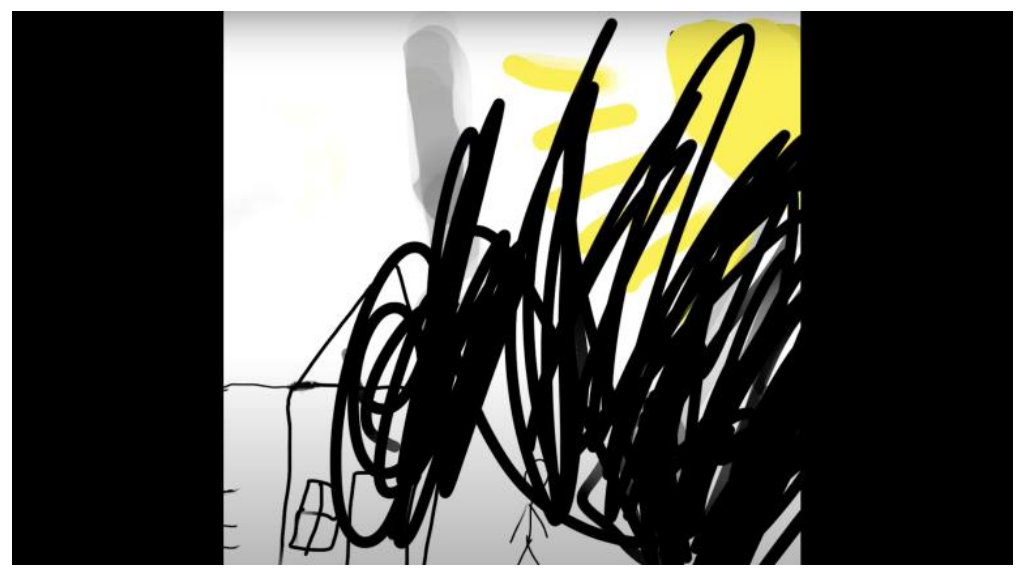

'Home' screen shot of Zoltar's digital animation in progress, East Melbourne 2019

When we talked about places of refuge the following week, as we do when building refuge tents with the children, Zoltar couldn't come to bring himself to draw anything that made him feel safe or at home. He did, however, feel motivated to invent new fortunes. Our field notes describe his engagement:

Zoltar drew his home today but the entire screen ended up black. He layered black patterns over black scribble. When I asked him what him and his family did at home, he said sleep. He said his dad sleeps a lot because he works a night shift. He seemed to have a disjointed relationship to his home. He felt constantly disappointed in himself and his art work and refused to keep trying with any drawing. Everything became a black scribble after the first attempt. I asked him about a lion he drew. I asked whether it shows his bravery? He said he wasn't brave. I also asked him what his favourite thing to do at home was. He said sleep. He said he slept because he was depressed, but then he laughed and said no, not really. 
I wonder whether he is depressed?

He told me his mother and father came over from Bosnia during the war... Is his connection to home shattered because of intergenerational trauma? Is he a descendent of survivors of the ethnic cleansing in Bosnia? This disconnect from home that made his drawings of home become black angry scribbles was also filled with a lot of anger and refusal to follow through with the exercise. On the last day, though he still struggled to follow along, I discovered that he liked to make paper airplanes and work with his hands and move his body. It was as if the tactile making made the art less confronting. He started to trust me, but still had a hard time opening up about identity or belonging or any of the core themes. It was as if he didn't know himself enough to speak or draw about it. In the end we made a hand held paper fortune teller together and he became the Magical 'Zoltar the Great'. He told people their fortunes during the art making in relation to symbols he had drawn on the four folded squares of paper (symbols are what we had talked about in our belonging conversations, what reminded us of home). After 3 days, we finally felt like he was happy and he seemed to be participating. It wasn't until he was telling fortunes about the future, not talking about his past, that he became invested in the art, and well, himself.

(Fieldnotes, East Melbourne, Aug 2019)

Zoltar's mother expressed fear of being Muslim in Australia. She mentioned during the focus group that she "doesn't watch tv anymore because they are just going to put something wild and loud and negative on the front page as opposed to something positive" (Ajša, Aug, 2019). She said that "it wasn't until I came to Australia that I heard about Muslims and terrorists, and I realised we weren't like that. I just wanted a path to follow" (Ajša, Aug, 2019). Ajša presents as detached from her immediate surroundings, stating that:

I love my family and everything, but I try not to get attached to these things. I remember Joanna's husband (points to a woman across the room) before he died, he was always dropping the kids off. It's like the bag (holds up her purse) you one day have it and the next day you don't have it. Like family you might 
have it, and then they are not there the next day. (Ajša, East Melbourne Focus Group, 2019)

Ajša could be one of the women whom Blackman describes as experiencing "worlds structured by inequalities and oppressions (racial, gendered, sexed and classed)" (2015, p.28) and her religion is clearly a necessary survival strategy needed "in order to endure" (2015, p.28). This fear of attachment is present for many refugees who have experienced trauma. Staci Haines' (2019) work in The Politics of Trauma: Somatics, Healing and Social Justice describes how:

trauma is an experience, series of experiences, and/or impacts from social conditions, that break or betray our inherent need for safety, belonging, and dignity. They are experiences that result in us having to vie between these inherent needs... For example, it might leave us with the impact of "I can be safe but not connected" (isolated). (p.74)

Zoltar and his mother's lack of attachment or need to belong shows how trauma sticks to bodies. How our cells are affected by lived experiences, which can be passed down from parents to children, biologically, socially, or pedagogically. Youdell (2016) joins together biological, social and environmental factors in looking at how children learn and asserts that "we find learning taken to be the making of memory, and memory taken as the biochemical changes in the brain that occur when something is learnt" (p.55-56). If memories can make changes, the agency of making futures for Zoltar certainly did as well. Through listening to Zoltar's embodied, aesthetic and biosocial orientations towards home and belonging, we worked with him to change in these ways he felt a limited capacity to act by providing a more open orientation towards making stories and fortunes about the future.

\section{Caleb's Rap Song}

During our second round of fieldwork at an inner North Melbourne primary school in October 2019, we ran a workshop on belonging quilts. The belonging quilts are often the third lesson plan we draw on. Hickey-Moody has developed a set of 3-6 new materialist arts-based approaches to inquiry that explore feelings of community, identity and belonging, and, when run in conjunction with one another, open up lines of flight which work towards understanding bodily affects and lived experiences of trauma in children's lives. This is the same workshop structure that generated Amira's 
story above. Getting the children to make quilt squares about identity and belonging proved more difficult for some than others. The two boys who really would not engage in the North Melbourne site live in the same housing block and come from similar refugee backgrounds.

Abdul and Caleb are first generation Australian boys from refugee families that fled Somalia and West Papua New Guinea before they were born. They live in the council housing block near the school. There is a class divide between those who live on the council housing estate and those who live in private housing in the area, while the housing estate serves a much needed purpose of providing shelter it also reinforces a class system: "the great class divide [that] opens up the possibility of a longing for expansion that not only has no economic possibility for expression but also equally has to be understood in terms of the psychosocial affective history of its production" (Walkerdine 2017 p. 6).

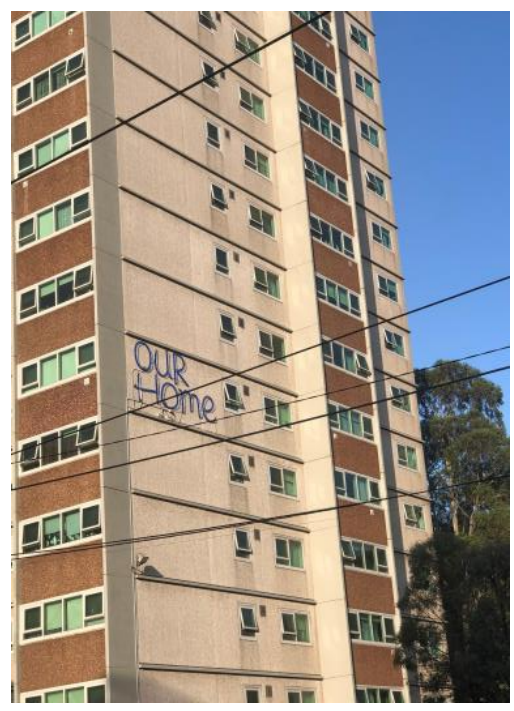

"Our Home" blue fluorescent light art on Caleb and Abul's housing block, North Melbourne 2019

In the conversation we had at the beginning of this round of arts workshops on belonging, Caleb ironically asserted to us that he lived in the very well to do suburb of Toorak, because his 'dad had a big house there'. Confirming this wasn't true, later that afternoon when walking home we noticed this sign that reads "our home" installed on the side of Caleb and Abduls' housing estate. It reads like a proud statement, but the new neon light sign that shines blue after dark also contrasts with the rundown building. As a symbol, in comparison to Caleb's imaginary home in Toorak, the light art seems to point to the struggles refugee families go through when moving across oceans, to find a safe home. Pedwell's (2016) argument on transnational affect asks 
us how we can have empathy that is not a form of colonial power. We do not live in these council towers, but by asking the boys to reflect on places they belong, this showed us how sensitive they are to intersecting issues of class and race that are expressed through home and belonging. They belong and do not belong to their home at the same time. Pedwell asks us "to think through the possibilities of empathy and/as translation. What might it mean to understand empathy not as emotional equivalence... but instead as a complex and ongoing set of translational processes involving conflict, negotiation and attunement?" (p.41). Thinking through the politics of empathy transnationally opens up possibilities for thinking and feeling across age, race and gender. Walking past our child participant's council housing estates on the way home from fieldwork we are reminded that belonging can be attachment to conflict and negotiation.

During this set of workshops Caleb and Abdul started to grow disinterested, disruptive, they tried to speak out, act out and assert dominance over the group. Age played a factor, as they were 9-10 years old and clearly beginning to grow into what they saw as their gendered role: spreading out, taking up space, seeking attention. This act of 'performing boy' as Bohlmann and Hickey-Moody (2019) have argued elsewhere, is a way of understanding how "meaning becomes contingent rather than fixed. As a sign, the child enters into an assemblage with other signs where meaning is composed in relation to those other elements, affectively, temporarily and provisionally" (p.7). Therefore, through the act of associating themselves with societal norms attributed to boys, children start to take up the gendered assemblages that surround them and assert these through performative acts. For the second week of workshops, we decided that Caleb and Abdul would do a different activity that was designed specifically to engage them in something they were more interested in: rapping.

Caleb's passionate rapping of Stormzy songs for the entire first day of the workshop, in active avoidance of any engagement with textiles, led us to think that rapping was something he wanted to do. To mitigate disruption to the rest of the class and to ensure they were enjoying the workshop, we encouraged the boys to tell their belonging stories through making a rap song instead of a quilt square. 


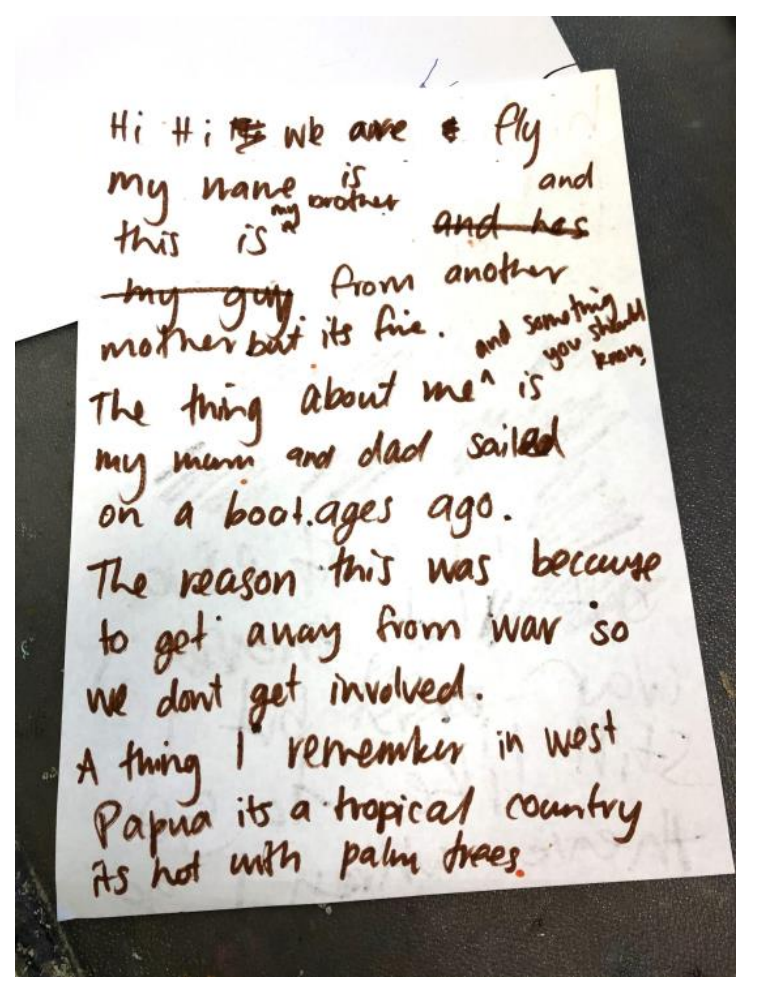

Caleb's rap song about home and belonging, North Melbourne, 2019

Their raps, Caleb's in particular, stood out for the way it charted his families' migration from West Papua New Guinea during the civil war, and the memory of the trees and the heat. His song of belonging highlighted his family's search for safety. The rap lyrics, also reproduced in the image above, read:

$\mathrm{Hi}, \mathrm{Hi}$, we are fly.

My name is Caleb and this is my brother Abdul, he's from another mother but it's fine.

The thing about me, and something you should know, my Mum and Dad sailed on a boat ages ago.

The reason this was because, to get away from war so we don't get involved. A thing I remember in West Papua it's a tropical country, it's hot with palm trees. (Caleb's rap, North Melbourne, 2019) 


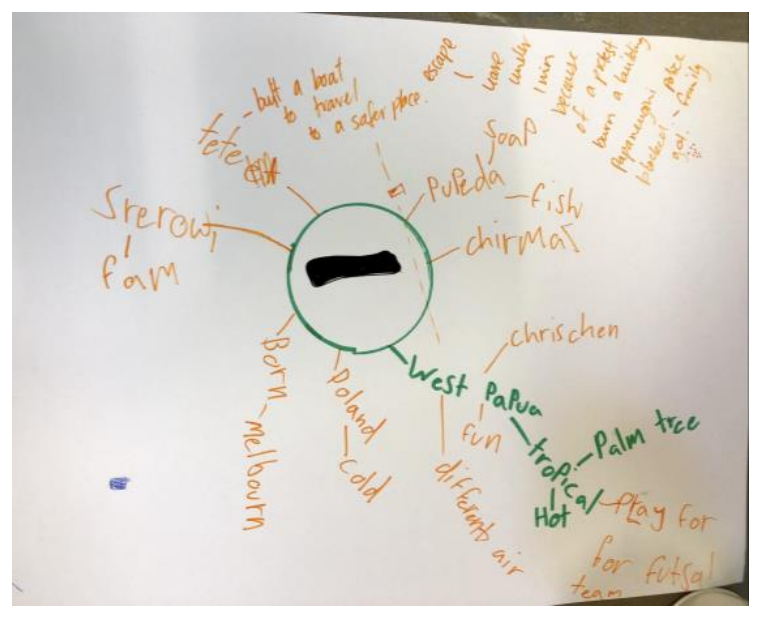

Mind mapping identity and belonging, North Melbourne 2019

Caleb's mind map above also shows him charting out ideas around identity and belonging to create the lyrics to his rap, which speaks to his connection to his family's history and their escape from war. We looked at the ways Caleb expresses himself through acting out with his body, by being loud and taking up space. For his relatively small size, he asserts dominance and is actively growing into his learned black male subjectivity through rapping. However, in his rap about belonging, we noticed his body change as he spoke about his family's use of a boat to flee to safety. Caleb said they only had one minute to get their things. He grew quiet, small, retracted into himself remembering this experience. When he rapped the escape, you could barely hear his voice, which was a stark comparison to earlier in the workshop when his voice was the only one you could hear shouting for attention.

Through this rap on belonging and story about identity, culture and home, we witnessed and were a part of, Caleb's embodied change. Caleb charted his family's emotional and physical past through his rap and also through his everyday actions of embodying what it means to be a black boy in Melbourne's inner north. Reading the child's body and the associated economies of affect, of expansion, contraction and change, Caleb's rap lyrics and visual stories told through the quilt tiles he subsequently produced expressed his bodily affects. Materially expressing things that can be difficult to articulate (Hickey-Moody and Willcox, 2020), is a way of thinking through the affected states of the body, and in some instances, helps the body to think through the ways it can change. For after a day of workshopping that was separate to the remainder of the class, Caleb's eagerness to take part in the group activity made his outbursts much less frequent. His bodily reaction to both rapping about home, and to 
speaking out and asserting dominance over the group spoke to the many ways feminist affect can be used as a tool for thinking through the child's body, and its many expressions of bodily affect.

\section{Conclusion}

The generational trauma of fleeing ethnic and religious wars stays with families, in lived experiences of first generation children, and, as Sangalang and Vang (2017) point out "there is increased recognition that war-related post-traumatic stress extends beyond the individual to affect families, with potential long-term effects on the health and psychosocial well-being of individuals in subsequent generations" (p.745). The bodily affects of years of fear, violence and war can stay in cells. Our bodies remember.

Feminist new materialist and intersectional thinking is a significant resource for understanding these economies of embodied change. Often such change entails shifting intergenerational trauma through biosocial processes of learning. The scholars' work we have used in this analysis is united by an interest in the materiality of change, the politics of aesthetics, embodiment, and knowledge production. This concern with the embodied politics of knowledge production can be reframed as a challenge, or a question:

How can we theorize the rich worlds of affective production through the history of feminist scholarship?

We would suggest that Iris van der Tuin (2014) (after Elizabeth Grosz) gives us a methodological answer to this question in arguing for feminist genealogy as a means for locating "the surprise for the future that we find in the past" (p. 10). A surprise of feminist futuring, in which women thinking with (and through) the work of other women, affects broader fields of scholarship and, in turn, informs the composition of the academy. May we be moved to change bodies of thought.

For Amira, Zoltar and Caleb, generational trauma descending through refugee families marks their art and their bodily affects. When talking about home and belonging, we think through the body, as it manifests certain ways of being that account for the body remembering trauma, war, searching for safety. Likewise, when making art about the 
future, about community or making the self through action and materiality, we recognize the power of feminist affect as a tool for understanding embodied trauma, but also for hopeful potentialities for our participants. Speaking to our earlier question, "How can we theorize the rich worlds of affective production through the history of feminist scholarship?" We offer the analysis in this paper as a route towards understanding children's bodily experience and expression, in ways that account for affective lines of inquiry pioneered by feminist scholarship.

\section{Bibliography}

Bergson, Henri Louis (1988). Matter and memory (Matière et mémoire) (N. M. Paul \& W. S. Palmer, Trans.). Brooklyn, NY: Zone Book.

Blackman, Lisa (2015). Affective politics, debility and hearing voices: towards a feminist politics of ordinary suffering. Feminist Review, 111(1), 25-41. doi:10.1057/fr.2015.24.

Bohlmann, Markus \& Hickey-Moody, Anna (Eds.). (2019). Deleuze and children. Edinburgh, UK: Edinburgh University Press.

Brownlie, Julie \& Sheach Leith, Valierie (2011). Social bundles: Thinking through the infant body. Childhood, 18(2), 196-210. doi.org/10.1177/0907568210394879

Bühlmann, Vera, Colman, Felicity \& van der Tuin, Iris (2017). Introduction to New Materialist Genealogies: New Materialisms, Novel Mentalities, Quantum Literacy. the minnesota review, (88): 47-58. doi: https://doi.org/10.1215/00265667-3787378

Coffey, Julia (2013). Bodies, body work and gender: Exploring a Deleuzian approach. Journal of Gender Studies, 22(1), 3-16.

Clough, Patricia \& Halley, Jean (Eds.). (2007). The affective turn: Theorizing the social. Durham: Duke University Press.

Cvetkovich, Ann (2012). Depression: A public feeling. Durham and London: Duke University Press.

de Frietas, Elisabeth \& Sinclair, Natalie (2013) 'New materialist ontologies in mathematics education: the body in/of mathematics' Educational Studies in Mathematics 83 453-470.

Deleuze, G. (1990). The logic of sense. New York: Columbia University Press.

Deleuze, G. (1988). A thousand plateaus. (B. Massumi, Trans. Vol. 2). London and New York: Continuum.

Deleuze, Gilles \& Guattari, Felix (1998). What is philosophy? (H. Tomlison \& G. Burchell, Trans.). New York: Columbia University Press. 
Frankiln-Phipps, Asilia (2017) Entangled Bodies: Black Girls Becoming-Molecular Cultural Studies <-> Critical Methodologies 17 (5) 384-391.

Gallop, Jane (1990). Thinking through the body. USA: Columbia University Press.

Haines, Staici (2019). The Politics of Trauma: Somatics, Healing and Social Justice. California, USA: North Atlantic Books.

Hickey-Moody, Anna. (2009). Unimaginable bodies. Leiden, The Netherlands: Brill | Sense.

Hickey-Moody, Anna. (2013). Youth, Arts and Education. Abingdon: Routledge.

Hickey-Moody, Anna. (2017). Arts practice as method, urban spaces and intra-active faiths. International Journal of Inclusive Education, 21(11), 1083-1096.

Hickey-Moody, Anna. (2018). Materialising the social: Art Practice as a Transversal Methodology. Ruukuu: Studies in Artistic Reseach (9).

Hickey-Moody, Anna \& Willcox, Marissa (2019). Entanglements of Difference as Community Togetherness: Faith, Art and Feminism. Social Sciences, 8(9), 264.

Hickey-Moody, Anna (2019). Deleuze and Masculinity. Palgrave Macmillan.

Hickey-Moody, Anna \& Willcox, Marissa (2020). Material expressions of religious culture: Faith, flows and futures. In C. Gomes and O. Woods (Eds.), Religion, Hypermobility and Digital Media in Global Asia: Faith, Flows and Fellowship. Amsterdam, The Netherlands: Amsterdam University Press. In press.

Kalmanowitz, Debra \& Ho, Rainbow (2016). Out of our mind. Art therapy and mindfulness with refugees, political violence and trauma. The arts in psychotherapy, 49, 57-65.

Kalmanowitz, Debra \& Ho, Rainbow (2017). Art therapy and mindfulness with survivors of political violence: A qualitative study. Psychological Trauma: Theory, Research, Practice, and Policy, 9 (Suppl 1), 107-113. https://doi.org/10.1037/tra0000174

Kluchin, Abigail (2012). The allure of affect: Rigor, style, and unintelligibility in Kristeva and Irigaray. (Doctoral dissertation). Retreived from Columbia University Research Repository. (0054D_10673).

Lugones Maria (2016) The Coloniality of Gender. In: Harcourt W. (eds) The Palgrave Handbook of Gender and Development. Palgrave Macmillan, London

Malone, Karen (2016) Theorizing a child-dog encounter in the slums of La Paz using post-humanistic approaches in order to disrupt universalisms in current 'child in nature' debates, Children's

Geographies, 14:4, 390-

407, DOI: $10.1080 / 14733285.2015 .1077369$

Massumi, Brian (1995). Autonomy of affect. Cultural Critique (31, The Politics of Systems and Environment Part II (Autumn 1995)), 83-109. 
Menakem, Resmaa (2017). My Grandmother's hands: Racialized trauma and the pathway to mending our hearts and bodies. Central Recovery Press.

Miller, Oliva, Shakespeare-Finch, Jane, Bruenig, Dagmar \& Mehta, Divya (2020). DNA methylation of NR3C1 and FKBP5 is associated with posttraumatic stress disorder, posttraumatic growth, and resilience. Psychological Trauma: Theory, Research, Practice, and Policy.

Niccolini, Alyssa (2016). Terror(ism) in the classroom: Censorship, affect and uncivil bodies. International Journal of Qualitative Studies in Education, 29(7), 893-910. doi:10.1080/09518398.2016.1174897

Pedwell, Carolyn (2016). De-colonising empathy: Thinking affect transnationally. Samyukta: A Journal of Women's Studies, 16(1), 27-49Rowe, C., Watson-Ormond, R., English, L., Rubesin, H., Marshall, A., Linton, K., ... \& Eng, E. (2017). Evaluating art therapy to heal the effects of trauma among refugee youth: The Burma art therapy program evaluation. Health promotion practice, 18(1), 26-33.

Sangalang, Cindy \& Vang, Cindy (2017). Intergenerational trauma in refugee families: a systematic review. Journal of immigrant and minority health, 19(3), 745-754.

Spinoza, Baruch (1996). Ethics (E. M. Curley \& S. Hampshire Trans., 6th ed.). London: Penguin Classics (Original work published in 1677).

Tomkins, Silvan (1962). Affect imagery and consciousness: The positive affects (Vol. 1). New York: Springer.

Tomkins, Silvan (1984). Affect theory. In K. R. S Scherer \& P. Ekman (Eds.), Approaches to emotion (pp. 163-195). Hillsdale NJ: Lawrence Erlbaum.

Tomkins, Silvan (1992). Affect imagery and consciousness: The positive affects (Vol. 4). New York: Springer.

Ugurlu, Nilay, Akca, Leyla \& Acarturk, Ceren (2016). An art therapy intervention for symptoms of post-traumatic stress, depression and anxiety among Syrian refugee children. Vulnerable children and youth studies, 11(2), 89-102.

Van der Kolk, Bessel (2014). The body keeps the score: Mind, brain and body in the transformation of trauma. Penguin UK.

van der Tuin, Iris (2009). The arena of feminism: Simone de Beauvoir and the history of feminism. In Doing Gender in Media, Art and Culture, 19-35. Routledge.

van der Tuin, Iris (2014). Generational feminism: New materialist introduction to a generative approach. Lanham, MD: Lexington Books.

van der Tuin, Iris (2016). The Feminist Futures of Reading Diffractively : Replacing Conflict-based Readings in the Case of Beauvoir and Irigaray. Rhizomes: Cultural Studies in Emerging Knowledge, (30) doi:10.20415/rhiz/030 
Walkerdine, Valerie (2016). Affective history, working-class communities and selfdetermination. The Sociological Review, 64(4), 699-714. doi:10.1111/1467$954 \times .12435$

Walkerdine, Valerie (2017). Of dinosaurs and divas: is class still relevant to feminist research? Subjectivity, 10(1), 1-12. doi:10.1057/s41286-016-0021-7

Youdell, Deborah (2016). A biosocial education future? Research in Education, 96(1), 52-61. 